Лидија Беко

Универзитет у Београду

Рударско-геолошки факултет

Наиље Маља Имами

Универзитет у Београду

Филолошки факултет
$371.3:: 005.94$

https://doi.org/10.18485/climb.2017.5.2.ch20

\title{
УПРАВЉАЊЕ ЗНАЊЕМ ПУТЕМ CLIL-A НА РГФ-У И СТВАРАЊЕ НОВИХ ОБЛИКА КУЛТУРЕ
}

\section{Сажетак}

Рад се бави аспектима теорије управљања знањем која је пореклом из економије и оним које заговара савремена педагогија CLIL наставе. Настојећи да понудимо идентификацију кључних начела и једне и друге области као и јасну подударност консеквентих решења, намера рада је да потврди вредности CLIL рационале кроз осведочене принципе управљања укупним квалитетом који постоје у пракси већ дуги низ година. Линијом поредбеног посматрања, уочавамо да CLIL педагогија са нагласком на тимски и колаборативни рад, ригорозну SWOT анализу, динамичност учења бројних компетенција и професионализацију, а не само едуцентризам, тежи организационој и квалитативној структури која је готово идентична обрасцима управљања укупним квалитетом. Учење у условима квалитета ствара ново образовно и професионално језгро у коме и предавачи и студенти имају разлог за понос. Култура се овде перципира не само као баштина, чување традиције и прошлости уз интеркултурално разумевање са другим народима, већ и активно стварање нових културних ставова, образаца и светова који се смишљено и спонтано креирају током учења.

Кључне речи: управљање знањем, управљање укупним квалитетом, култура, квалитет наставе.

\section{1. Увод}

Савремена настава енглеског језика на Рударско-геолошком факултету пилотирањем CLIL приступа настоји да кроз квалитетан 
избор садржаја и успешан модел подучавања путем тимског и колаборативног рада, припреми студенте за успешну апликацију знања и компетенција у професионалном раду и каријери. Такође, у језичкој учионици интегрисане наставе, настојимо да унесемо сталну виталност и вредност културолошког приступа који би се у духу ауторке Доу Којл развијао, не као „роst scriptum, већ као нит која плете свој пут“ (Coyle 2005: 6), то јест, водећи принцип у учењу, заснован на интеграцији језика и контекста уз непрекидно „отварање интеркултуралних врата“" (Coyle $u$ дp. 2010: 39).

Од посебног је значаја, стога, да подручје интегрисане наставе језика и садржаја буде у стању континуираног корелирања са предметима геологије и рударства, да рад током наставе негује сталну вредност кооперативности, као и да добром сарадњом са професорима стручних предмета одговоримо на изазове промена и потреба непрекидног побољшања квалитета и културе. Спровођење оваквих намера захтева анализу свих нових сегмената организације, то јест, образовно-менаџерско усклађивање следећих сегмената: тимског и колаборативног рада, SWOT анализе као предуслова доброг курикулума, управљања знањем и креирање наставних материјала, као и стварање нових облика културе.

\section{2. Тимски и колаборативни рад}

Језик је систем који се односи на оно што се говори (садржај), и средство којим се говори (исказ). Лингвистички садржај је неодвојив од исказа. При учењу садржаја, ми превиђамо улогу језика као медија учења, а при учењу језика превиђамо чињеничу да саопитавамо одређени садржај (Mohan, 1986:25).

Предуслов доброг подучавања на интегрисаној настави представља тимски рад, колаборатвини или ефективни тандемски рад са доменским професором. Ако се скафолдинг унутар учионице према Мехисту и сарадницима састоји од: неговања безбедног и богатог амбијента у коме студенти експериментишу са језиком и садржајем, у коме траже језичку помоћ када им је потребна у новим (непреведеним) доменским садржајима, ако негују креативно и 
Култура и/или наука

критичко мишљење о садржају, ако су потстицани да напусте зону комфора и начине нове кораке у истраживању (Mehisto u dp. 2008: 30-31), да поменемо само неке од кључних елемената рационале, постаје јасно да је сарадња са доменским професорима више него подразумевајућа. У томе почива и једна од најкрупнијих разлика између наставе језика струке и интегрисане наставе језика и садржаја. Стручњак за садржај подучава научне аспекте садржаја, а језички стручњак подучава језичке аспекте садржаја. Напредак у језику не зависи само од предавача језика, већ и од доменског предавача или од њиховог заједничког рада. Заједничко присуство на часу није обавезно, али је интердисциплинарност подразумевајућа (Navés 2009: 34). Мехистов цитат који се налази на почетку поглавља представља парадокс на коме се темељи CLIL приступ. Наиме, језик и садржај су целина, језик укључује и значење и форму, а језички дискурс изражава, али и обликује садржај. Квалитетно подучавање утемељено на CLIL-y подразумева испреплетеност језичких и стручних садржаја, усвајање знања путем језика, који се касније у комуникативном контексту додатно проширује на низ језичких вештина којим се оно саопштава, попут преговарања, убеђивања или уверавања, посредовања, интервјуисања, јавног наступа итд.

Ширећи ову тему даље на конкретне савете како успоставити квалитетне облике сарадње са доменским професорима, корисну смерницу налазимо у често цитираном раду Бруса Такмана (Tuckman 2001: 71-72) који сматра да се сарадња унутар тима не дешава, већ да се развија, и то кроз четри фазе сарадње:

1. формирање (forming) је рана фаза у којој тим није тим, само скуп појединаца који имају заједничку сврху, али мало знају како да раде заједно. Постоји велики број емоција у вези са овом раном фазом, од узбуђења, оптимизма, идеализма, поноса, страха или сумње. Обрасци понашања могу бити расипничи када је реч о времену и труду, али они су природни и неопходни да би се уклонила сујета, понос, страх или неке друге баријере које постоје међу колегама

2. Друга фаза први потреси или олујна фаза (storming) када чланови могу негативно реаговати на изазове, када се стварају интерперсонална непријатељства, када због недостатка напретка и времена које се губи долази до сукоба. Ово непријатно раздобље се 
може решити стрпљењем, усвајањем заједничке агенде, хумором, чврстином и одлучношћу.

3. Трећа фаза позната као нормирање (norming) утврђује и развија методе рада тима, то је процес постављања правила, додељивања улога, исправљање дефиниција које не функционишу, структуирања заједничког приступа раду.

4. Обављање задатака (performing) је четврта фаза у процесу формирања тима када чланови развијају свој начин рада, изграђују идентиети улоге које намеравајуда остваре. Синергија групе је награда за добар тимски амбијент, где побољшање и стално договарање представља обавезу чак и за најискусније или најсигурније чланове тима.

Све поменуте карактеристике и искуства можемо примењивати касније током наставе у циљу креирања тандемског, тимског или колаборативног рада међу студентима, било да се ради о учењу: базираном на пројетку (project-based learning), учењу базираном на задатку (task-based learning), учењу базираном на проблему (problem -based learning), или учењу базираном на откривању или открићу (inquiry-based learning). Другим речима, елементе сарадње, ефикасности, кооперативности, амбиција и мотивације које будемо развијали и спроводили ми сами са доменским професором/има, уједно ће бити исти они којим ћемо подучавати студенте помажући им да формирају њихове облике сарадње или тимове. Уз то, побољшање властитог учинка и трансформација је циљ коме сваки предавач тежи, а оно што је препоручљиво за побољшање личних квалитета, ефикасније лидерство и оснажење професора, добро је и за студенте који би те исте обрасце усвајали.

Није стога сувишно нагласити још неке корисне карактеристике које чине успешне тимове, иако се мора нагласити, да смо свесни да не постоји један рецепт за све ситуације.

- Тим треба да има јасне циљеве, као и начине постизања (ако задатак нема смернице о изводљивости, онда ће „планина задатка“ бити сувише велика за освајање).

- Тим мора имати своје улоге, како би разумно користио свој основни ресурс: енергију (знати ко је лидер и шта је приоритет). Важно је користити енергију тима за побољшање, а не расипање, на развој и учинак, а не на расправе. 
Култура и/или наука

- Тим треба да има одговарајуће алате за решавање проблема (визуелни едитор је један од најкориснијих).

- Тим треба да развије стандарде понашања које укључују добру комуникацију што је од суштинског значаја, једнако као и поштење и интегритет чланова, њихову спремност да отворено сарађују, да деле своја мишљења без скривених намера (Scholtes 1988: 175).

Уколико наведене смернице искористимо за формирање партнерских или тимских односа унутар CLIL тимова, онда ће ce разумевање заједничких задатака, међузависност и сарадња одвијати у односима поверења, подршке и поштовања. Потенцијал CLIL усмерен на језик има заједничку сврху да дефинише циљни језик у његовом природном контексту. Страни језик као и матерњи увек се јавља у контексту. Ако се вратимо на Моханов парадокс са почетка поднаслова, долазимо да закључка да не постоји језик per se и да се сва значења праве управо кроз контекст. То значи да је језик увек социолошки, културолошки, психолошки и тексутално веома сензитиван у односу на контекст и у односу на њега га морамо дефинисати. Језик геологије или рударства, одражава оне контексте које и ствара, а језички предавач не може их декодирати без сарадње са доменским предавачем, као што доменски предавач није лингвистички компетентан да лексички и граматички понуди потпуну преводилачку прецизност појма или исказа.

\section{3. Свот анализа као предуслов доброг курикулума}

SWOT анализа постала је опште место стратешког планирања у образовању и најефикасније средство за лоцирање потенцијала одређене институције. У SWOT анализи, предности и мане су интерна ревизија ефикасности дате институдије, а претње и прилике су спољни аспекти контекста у којој институција ради. Анализом се издвајају кључна подручја који могу бити потенцијали за развој институције, повећање предности, минимализовање слабости, смањење ризика и развој конкурентности. Анализа се додатно ојачава фокусом на захтеве тржишта као и такмичарским или конкурентски аспектима у односу на конкуренцију. Ако се анализа комбинује са мисијом и 
визијом факултета, онда се долази до карактеристичне нише или идентитета који издвајају институцију од ривала. Дефинисање индентитета олакшава утврђивање даљих карактеристика квалитета установе.

У циљу дугорочних стратегија везаних за институцију, у овом случају РГФ, постоје две које су релевантне за CLIL. Прва стратегија је диференцирање факултета као јединствене институције у односу на окружење и конкуренцију. Јединсвеност и квалитет су важни за сваку институцију којатим путем жели да привуче пажњу и оствари алтернативне изворе финансирања. А друга стратегија укључује фокус на одређено подручје којим се иноварини прилагођава потребама циљних група, а са циљем да се стекне конкурентска предност. Још једном важно је истаћи да је квалитет једнако неопходан, јер фокус на студенте може бити успешан само ако задовољава својим квалитетом.

Фактори које треба имати на уму у креирању курикулума према SWOT анализи по ауторкама Герки, Џејкобс и Липсон са сарадницима јесу следећи: флексибилност у планирању, коришћење бројних елемената техничке подршке, квалитетни садржаји и концепти који се интегришу, веза између интеграције и исхода, обим и секвенцијалност курикулума, трансфер учења, флексибилне студентске групе, евалуација (Gehrke, 1991; Jakobs, 1989; Lipson u др. 1993). Избор тематских области је од суштинског значаја, теме промовишу повезивање појмова, доводе до дубљег разумевања, укључују активности и задатке, који ако нису довољно повезани нису од помоћи.

Интегрисани курикулум је средство, а не циљ или педагошки резултат. Лоше дизајниране јединице не постижу смисао дубљег разумевања и темељног учења, и сваки од елемената постаје изолована целина. Она представња такав спој где учење поприма сасвим нове димензије, смисао и садржај који превазилазе курикуларне изјаве и намере. У интегрисаној учионици, симултана настава концепата и компетенција, има већи ефекат од збира учења компетенција и концепата у појединим областима. Стога у укупности смерница добијених и интегрисаних у институционалне оквире интегирсане наставе сматрамо веома корињним и мишљење аутора 
Култура и/или наука

Хемфриза да ће студенти временом схватити како се ствари уклапају у настави према томе како их учимо. „Ако их учимо повезаности и интеграцији, они ће то и научити. Ако их учимо сегментацији и дисконтинуитету, то ће научити." (Humphreys и дp. 1981: хі).

\section{4. Управљање знањем и процена наставних материјала}

Ако се подсетимо на тренутак таксономије Андерсона и Кратвола, по којој се знање дели на:

- чињенично знање (factual knowledge): релевано за елементе одређене стручне области са припадајућом терминологијом

- концептуално знање (conceptual knowledge): релеванто за правила, поступке и теорије

- процедурално знање (procedural knowledge): релевантно за обављање одређених задатака и решавање проблема

- мета-когнитивнознање (meta-cognitive knowledge): релевантно за свест о стратегијама учења, аутономији и целоживотном учењу (Anderson и Krathwohl, 2001),

онда је јасно да ефикасно подучавање, утемељено на интегрисаном приступу, предочава усвајање професионалних и академских знања и вештина у чијем се средишту наставе налазе стручни, аутентични академски и ванкадесмски наставни материјали. Међутим, као што Васкез запажа: „како се сада чини, ретки су издавачи који се усуђују да публикују конкретне материјале, зато што је тржиште и даље веома мало, и није економски исплативо“ (Váskez, 2007:103). У случају геологије, оскудност наставних материјала је утолико већа што су они били изузетно малобројни и када је реч о језику за посебне намене. Трагајући за моделом сажимања комплексног подручја у облике прихватљиве за тренутак у коме живимо и потребе наших студената, ослонили смо се на модел у духу Парето ${ }^{1}$ промишљања који се базира на принципу 80/20. И то по два основа, по мишљењу Џурана (Juran, 1989), прво стандарде треба свести на оне који су у

Вилфредо Парето је био италијански економиста који је проценио да 20\% Италијана поседује $80 \%$ богатства Италије. Одатле је и настало правило да је $20 \%$ неке величине довољно да објасни $80 \%$ вредности те величине. 
складу са потребама ученика. Не треба их понижавати да уче оно што им у животу неће требати. Планирање квалитета доводи до његовог побољшања, а оно смисао добија само у практичној примени. Дакле само део (20\%) је довољан да би осликао целину (80\%), а лош квалитет који проистиче из подучавања резулат је лошег управљања, то јест $80 \%$ проблема лежи у управи, тј. предавачима.

\section{5. Култура}

Под тачком култура, и подтачком интеркултуралне способности, у Заједничком европском оквиру за живе језике налазе се следеће одреднице: а) способност успостављања односа између сопствене и стране културе; б) изграђивање позитивног доживљаја према самом појму културе и способност препознавања и употребе различитих стратегија у остваривању контаката са људима из другог културног миљеа; ц) способност посредовања између две културе и успеђно играђивање неспоразума и сукоба услед културних разлика; д) способност превазилажења површних односа који не прелазе ниво стереотипних представа (3ЕРОJ, 2003:118).

Сматрамо да је добар почетак планирања наставе управо последња тачка преформулисана као: превазилажење стереотипних представа о учењу и култури у језичкој учионици. У равни тог става, сматрамо да потребно мењати устаљене односе унутар учионице, традиционална мерила учења, ауторитета и квалитета. Ово је изузетно захтевно и потребно је време за спровођење. Неопходно је заправо урадити две ствари: прва је оно што се у економији зове каизен, а означава јапанску реч за континуирано побољшање или „корак-по-корак-побољшање“. Филозофија каизена је велика, инспиративна и свеобухватна, али је његова примена малог обима, високо практична и постепена. Џозеф Јуран сматра да драстичне интервенције нису сигурно средство промене, нити су грандиозне шеме корак напред (Juran, 1989). Суштину каизена чине мали кораци или пројекти који граде упсех, самопоуздање, развијају базу за даље унапређење. Аутор тврди да су најизводљивији задаци „величине залогаја“ (bite-sized), који обезбеђују трајне и чврсте промене. Низ 
Култура и/или наука

малих и остваривих промена и помака неопходно је правити за свако питање, сваки процес, сваку активност. Током времена, на овај начин, могу се покушати остварити и промене великих размера, или како то аутор назива промене „величине слона“ (elephant-sized) (uбид.)

Друго пратити трансформационе промене или како се радна култура мења у правцу квалитета. Инструментални параметри стављају нагласак на екстерну стандардизацију или квалитетан исход. То је поређење и проналажење доказа о раду или стандардизација исхода ускладу са мерним приступом раду. Она говори о подударности квалитета са унапред одређеном спецификацијом. Та спецификација може бити из надлежности Заједничког европског оквира за живе језике, неког од сертификата из нивоа Ц1 или Ц2 и слично. Међутим, да би се дошло до овог степена, неопходно је обезбедити окружење и климу која помаже да се тек у каснијим фазама развије нагласак на приступ сертификацијама. До тада, високи захтеви могу угушити креативност, мотивацију и иновацију. Трансформација или култура промена нема мерљивост, или мерљиву перформансу, посебно не у почетку. За разлику од тврдих показатеља или конкретних показатеља учинка, меки показатељи баве се осигурањем климе, амбијента са нагласком на сигурност, где је добробит студента приоритет, као и посвећеност студентима свих способности. Трансформациона култура није само организација и њено побољшање. Не ради се о томе да ствари радимо на прави начин, већ да радимо праве ствари. Оријентисани ка трансформационој култури, вежбамо не само студенте, форму, нове односе између професора, професора и студената, већ усвајамо један широк и еклектичан поглед на квалитет. Одговорност свих учесника, сваког појединачно у својој области, може у потпуности да допринесе његовом остварењу.

\section{6. Закључак}

Интегрисана настава је прагматички оријентисана настава која у свом коначном циљу настоји да задовољи потребе који произилазе из захтева тржишта рада где посебно важну улогу имају страни језици као средство међународне комуникације. Интегрисана 
настава садржаја и језика стога елиминише вештачку употребу језика и настоји да доменске области знања, у овом случају геологију и рударство, подучава унутар његовог природног лингвистичког „дома“. Иако је теорија управљања квалитетом, уосталом као и сам CLIL, богата слоганима и често цитираним фразама и представља шарени конгломерат модела и активности, у бази нашег модела налази се стари, добри и горди волонтаризам. Он у процесу имплементације настоји да буде максимално реалистичан, конкретан и ефикасан. У ту сврху, опредељен је на следеће: 1) тимски рад представља окосницу интегрисане наставе који није само систем већ њена суштина; 2) SWOT анализа и курикулум су грађевински блокови система, они као и тим не дешавају се природно већ пројектно и део су осмишљавања и планирања; 3) управљање знањем и наставни материјали имају своје слабе тачке у скромној понуди и непостојећем интересовању издавачких кућа, али са друге стране, и настојању предавача да конципирају знање по принципу „драгоцено мало“. Стога је неопходно на предавачи буду комуникатори знања, да подижу статус стручности својих студената кроз све облике рада и материјала, да деле знање и стучност и стварају поверење и културу развоја и етичности. Размена знања у условима трансформационе културе подразумева пријатељски амбијент у односу на грешке и погрешивост, као и подељену одговорност и иницијативу свих учесника у креирању нове образовне културе.

\section{Извори и литература}

Anderson, Lorin, and David Krathwohl. A Taxonomy for Language Learning, Teaching and Assessment, New York: Longman, 2001.

Coyle, Do. Planning Tools for Teachers, the University Of Nottingham School Of Education, 2005. Доступно на: http://www.slideshare.net/gorettiblanch/theoretical-framerwork [сајту приступљено: 7. фебруара 2017].

Coyle, Do, Peter Hood and David Marsh. Content and Language Integrated Learning. Cambridge: Cambridge University Press, 2010.

Gehrke, Nathalie. Explorations of Teachers Development of Integrative Curriculums, Journal of Curriculum Supervision 6/2 (1991): 107-112.

Humphreys, Alan, Thomas Post and Arthur Ellis. Interdisciplinary Methods: A Thematic Approach. Santa Monica, CA: Goodyear Publishing Company, 1981. 
Култура и/или наука

Jakobs, Heidi. Interdisciplinary Curriculum: Design and Implementation. Alexandria, VA: Association for Supervision and Curriculum Development, 1989.

Juran, Joseph. Juran on Leadership for Quality, Macmillan, New York, 1989.

Lipson, Marjorie, Sheila Valencia, Karen Wixson and Charles Peters. Integration and Thematic Teaching: Integration to Improve Teaching and Learning, Language Arts 70/4 (1993): 252-264.

Mehisto, Peeter, David Marsh and Maria Frigols. Uncovering: Content and Language Integrated Learning in Bilingual and Multilingual Education. Oxford: Macmillan, 2008.

Mohan, Bernard. Language and content, Reading, MA: Addison-Wesley, 1986.

Navés, Theresa. "Effective programmes". In Ruiz de Zarobe, Y. and Jimenez Catalan, R.M. (eds.): Evidence From Research in Europe. Bristol: Multilingual Matter, 2009.

ZEROJ . Заједнички европски оквир за живе језике. Подгорица: Министарство просвјете и спорта, (2002).

Scholtes, Peter. The Team Handbook, Madison, WI: Joiner Associates Inc, 1988.

Tuckman, Bruce (Spring 2001). Developmental Sequence in Small Groups. Group Facilitation: A Research and Applications Journal: 71-72. Доступно на: http://dennislearningcenter.osu.edu/references/GROUP\%20DEV\%20ARTICLE.doc. [сајту приступљено 23 маја 2017].

Vásquez, Graciela. Models of: An Evaluation of its Status Drawing on the German Experience. A Critical Report on the Limits of reality and Perspectives, Volumen Mongoráfico (2007): 95-111.

\section{Lidija Beko}

University of Belgrade

Faculty of Mining and Geology

Nailje Imami

University of Belgrade

Faculty of Philology

\section{KNOWLEDGE MANAGEMENT AT THE FMG AND THE CREATION OF NEW FORMS OF CULTURE}

\section{Summary}

The paper deals with overlapping aspects that are observed in the theory of knowledge coming from the economy and those advocated by modern pedagogy of CLIL teaching. Striving to offer identification of key principles of both scientific fields and a 


\begin{abstract}
clear correlation among consistent solutions, the intention of the paper is to verify the value of the demonstrated CLIL principles in the light of total quality management which have existed in practice for many years. In the line of comparative observation, we see that the CLIL approach, as pedagogy with an emphasis on teamwork and collaborative work, rigorous SWOT analysis, harmonized with established standards, learning dynamics in the direction of a number of competences, professionalization and not just educentrism, strives for organizational and qualitative substance that is almost identical to the patterns of total quality management. Learning, in terms of quality, creates a new educational and professional core in which educators and students have reason to be proud. Culture is perceived not only as a heritage, preservation of tradition and the past with the intercultural understanding of other nations, but it also actively creates new cultural attitudes, forms and worlds that are deliberately and spontaneously being born during learning.
\end{abstract}

Key words: knowledge management, total quality management, culture, quality teaching 